\title{
Budget Policies During and After the Oil Crisis of 2014: Comparative Analysis of Saudi Arabia, UAE, and Kuwait
}

\author{
Abdulaziz A. Alotaibi ${ }^{1}$ \\ ${ }^{1}$ Department Chair, Public Administration Department, College of Business, King Saud University, Saudi Arabia \\ Correspondence: Abdulaziz A. Alotaibi, College of Business Administration, King Saud University, PO BOX \\ 71115 Riyadh 11587, Saudi Arabia.
}

Received: April 10, 2019

Accepted: May 5, 2019 Online Published: May 16, 2019

doi:10.5539/ibr.v12n6p23

URL: https://doi.org/10.5539/ibr.v12n6p23

\begin{abstract}
This paper explored how some Gulf Cooperation Council (GCC) countries employed budget policies to manage their budget deficits in the fiscal years between 2014 and 2018. Empirically, this study attempted to summarize and critically analyze several approaches of economic strategies that countries utilized such as sovereign wealth fund, revenue-increasing policies, and expenditure-reducing policies in response to budget deficits during and after the oil crisis of 2014. Secondary data were gathered from the ministry of finance reports as well as various official documents covering three different GCC countries, which are Saudi Arabia, UAE and Kuwait. The findings of this study showed distinct patterns in a three-country approach to manage their budget deficits. Saudi Arabia and UAE implemented a comparatively more balanced approach between increasing revenues and reducing expenditure. On the other hand, Kuwait focused on reducing their budget expenditures and adopted policies that promoted across the board cuts and is relatively relying more on oil revenues to balance the budget.
\end{abstract}

Keywords: public policy, public budget, budget policy, budget deficit, budget-balancing policy

\section{Introduction}

This study explored how three different country-members of the Gulf Cooperation Council (GCC), which are Saudi Arabia, United Arab Emirates (UAE), and Kuwait, responded to their budget deficits during and after the oil crisis of 2014. In particular, the study contributed to the literature by conducting a comparison of the various budget-balancing strategies that these countries have utilized to address their budget challenges. A budget deficit is generally defined as "the fiscal condition in which state government revenues are short in providing for the cost of its promised services" (Shi, 2016, p 27). Contrary to previous economic recessions, the current oil crisis impacted countries' budget revenues to a greater extent. Beginning from Fiscal Year (FY) 2014 and through FY 2015 and FY 2016, the economic conditions in almost all GCC countries became significantly difficult (Altman \& Haass, 2010; Bouri, 2015; El-Katiri, 2016; Sultan \& Haque, 2018).

This study helped in understanding the influence of public policy on the budget. In 2014, public budget for the three GCC countries shrunk to historical standards. These countries were obligated to find alternative revenue resources to make up for the lost in budget. There were three main budget-balancing strategies that these countries considered to close the gap in the budget, which are withdrawing from the sovereign wealth fund, implementing revenue-increasing policies, and/or adopting expenditure-reducing policies (Shi, 2016; Presley \& Westaway, 2017; Sultan \& Haque, 2018). However, the question remains whether there are different patterns in budget-balancing strategies between countries; and how the different policies could have influenced the budget (Alkhateeb, Sultan, \& Mahmood, 2017; Fattouh, Poudineh, \& Sen, 2015).

The secondary data collected from the ministries of finance reports showed that the three GCC countries have utilized different types of budget-balancing strategies to manage their budget shortfall (IMF, 2019; Presley \& Westaway, 2017). For GCC governments, budget deficits were more likely to be significantly reduced when a balanced approach is considered. However, the use of expenditure-reducing policies such as across the budget cuts or employee benefits cuts were less likely to improve the budget (Maghyereh, Awartani, \& Tziogkidis, 2017; Haque \& Khan, 2019).

\section{Literature Review}

When a budget shortfall occurs, broad arrays of strategies and policies are considered to fight budget deficits 
(Ndjokou, 2013). An examination of these strategies within the context of the oil crisis of 2014 provides pivotal information for the reader and the literature. There are three main types of budget-balancing strategies that the literature offers, which are the utilization of sovereign wealth fund, revenue-increasing strategies and expenditure-reducing strategies (Truman, 2009; Shi, 2016; Maghyereh, Awartani, \& Tziogkidis, 2017; Alkhateeb, Sultan, \& Mahmood, 2017; Sultan \& Haque, 2018). Below, a discussion of each category is provided.

First, the sovereign wealth fund is a country's savings or financial reserves, often named "budget stabilization fund" or "rainy days fund." In times of strong economy, countries put budget-surplus in a fund for use in times of unanticipated budget shortfalls (Shi, 2016). The fund is also known to be a low-risk investment that governments consider in order to continue providing civil and other services to their citizens without having to increase tax that might exacerbate an economic downturn (Shi, 2016; Truman, 2009). However, the mere existence of sovereign wealth fund does not guarantee the avoidance of hardship during severe budget shortfall. In fact, during the 2014 economic recessions almost all GCC countries implemented other strategies to balance their public budget (Maghyereh, Awartani, \& Tziogkidis, 2017; Sultan \& Haque, 2018).

Second, revenue-increasing strategies aim to grow the economy by implementing policies that enhance budget revenues without severely affecting public spending or creating market hostility (Ndjokou, 2013; Garcia \& Hénin, 1999). Implementing revenue-increasing strategies during economic recessions can be extremely challenging. In economic recessions, government revenues decrease significantly and markets become particularly sensitive to government policies that aim to close the gap in the budget, especially if these revenue-increasing policies come in the form of rising major tax sources such as the value added tax (VAT) or implementing new taxes and fees (Ivanova, Romanova, Kostoglodova, \& Romanov, 2017; Maghyereh, Awartani, $\&$ Sweidan, 2017).

Third, expenditure-reducing strategies are commonly known as a mid-year budget cuts that governments employ during economic recessions in order to avoid severe budget deficits (Shi, 2016; Garcia \& Hénin, 1999). In fact, governments are forced to utilize such strategies in order to cope with the heavy pressures from severe declines in revenue collections and increasing expenditure demands (Raudla, Douglas, Savi, \& Randma-Liiv, 2017). Forms of expenditure-reducing strategies include employee benefits cut, subsidies cut, and across the board budget cuts (Shi, 2016; Alkhateeb, Sultan, \& Mahmood, 2017).

\section{Methods}

This is a comparative study that utilizes secondary data in order to analyze the budget balancing strategies implemented by three GCC countries. Comparative analysis is a method that researchers use in order to explain a subject matter that cannot be studied without comparing on the bases of logical reasoning (Ragin, 1987). The data are adopted from the financial reports produced by the ministries of finance in the three GCC countries, which are: Saudi Arabia, UAE, and Kuwait from 2014-2018 to analyze the budget balancing strategies that these countries adopted to cope with the oil crisis of 2014. Some of these reports were unpublished; however, they are supplemented to the author via office visits.

\section{Results}

Results showed that the oil crisis of 2014 had significantly increased budget deficits for all three GCC countries indicating the huge reliance on oil revenues as the single major source for budget revenue. Table 1 showed how Saudi Arabia was able to significantly reduce their annual budget deficit to about $4 \%$ to GDP. However, Kuwait experienced relatively high budget deficit during the FY 2016 and FY 2017 in which oil prices were at their lowest rates. On the other hand, the UAE maintained their budget deficit within similar ranges during the intense period of the oil crisis (FY 2016 and FY 2017).

Table 1. The Dollar Amount and Percentage of Budget Deficits for Saudi Arabia, UAE and Kuwait for Fiscal Years 2014-2018

\begin{tabular}{|c|c|c|c|c|c|c|c|c|c|c|}
\hline \multirow[b]{2}{*}{ Country } & \multicolumn{2}{|c|}{ FY 2014* } & \multicolumn{2}{|c|}{ FY 2015* } & \multicolumn{2}{|c|}{ FY 2016* } & \multicolumn{2}{|c|}{ FY 2017* } & \multicolumn{2}{|c|}{ FY 2018** } \\
\hline & $\$$ & $\%$ & $\$$ & $\%$ & $\$$ & $\%$ & $\$$ & $\%$ & $\$$ & $\%$ \\
\hline Saudi Arabia & -103 & 16 & -83 & 13 & -63 & 9 & -36 & 5 & -35 & 4 \\
\hline UAE & -62 & 15 & -66 & 18 & -72 & 20 & -75 & 20 & -80 & 18 \\
\hline Kuwait & -24 & 14 & -19 & 16 & -32 & 29 & -26 & 21 & -20 & 13 \\
\hline
\end{tabular}

Source: The World Bank*, MOF of Saudi Arabia, UAE, and Kuwait**

Note: Dollars in Billions of US Dollars. \% Of budget deficits is measured by the total amount of budget deficits as a percentage of general fund expenditure.

GCC countries rely heavily on oil production for their budget revenues. Table 2 showed how oil crisis of 2014 
had drastically decrease GDP for Saudi Arabia, UAE, and Kuwait for the FY 2015 and FY 2016. However, the UAE was relatively more able to significantly increase their budget revenues and overcome their budget shortfall. On the other hand, in FY 2018, Saudi Arabia was only 1\% short from exceeding their GDP in FY 2014. As for Kuwait, the GDP shrunk significantly and is $12 \%$ away from meeting their GDP in FY 2014. One of the main reasons for such results is that UAE and Saudi Arabia has implemented more revenue expansion strategies such as value added tax (VAT) and new fees and taxes, whereas Kuwait focused more on budget cuts and relied comparatively more on oil production for budget revenues.

Table 2. The GDP (\$) and Annual Growth (\%) for Saudi Arabia, UAE and Kuwait for Fiscal Years 2014-2018

\begin{tabular}{|c|c|c|c|c|c|c|c|c|c|c|}
\hline \multirow[b]{2}{*}{ Country } & \multicolumn{2}{|c|}{ FY 2014* } & \multicolumn{2}{|c|}{ FY 2015* } & \multicolumn{2}{|c|}{ FY 2016* } & \multicolumn{2}{|c|}{ FY 2017* } & \multicolumn{2}{|c|}{ FY 2018} \\
\hline & $\$$ & $\%$ & $\$$ & $\%$ & $\$$ & $\%$ & $\$$ & $\%$ & $\$$ & $\%$ \\
\hline Saudi Arabia & 756 & 3.7 & 654 & 4.1 & 644 & 1.7 & 686 & -0.9 & 745 & 2.3 \\
\hline UAE & 403 & 4.4 & 358 & 5.1 & 357 & 3 & 383 & .8 & 432 & 2 \\
\hline Kuwait & 162 & 0.5 & 114 & 0.6 & 110 & 3.5 & 120 & -2.9 & 144 & 1.7 \\
\hline
\end{tabular}

Source: The World Bank*, MOF of Saudi Arabia, UAE, and Kuwait**

In table 3, the inflation rates between the three GCC countries are compared. Inflation, often expressed as a percentage, indicates the purchasing power of a nation's currency (Haque \& Khan, 2019; Fattouh, Poudineh, \& Sen, 2015). In 2016, Saudi Arabia implemented an employee benefits cuts in order reduce budget expenditure. However, this action may have contributed to the deflation that the country experienced as public purchasing power decreased. The UAE maintained relatively a normal range of inflation rates. However, Kuwait experienced a lower inflation rate in 2018, which could indicate that budget cuts might have slightly affected public purchasing power.

Table 3. The Inflation Rate (\%) for Saudi Arabia, UAE and Kuwait for Fiscal Years 2014-2018

\begin{tabular}{llllll}
\hline & FY 2014* & FY 2015* & FY 2016* & FY 2017* & FY 2018** \\
\cline { 2 - 6 } Country & $\%$ & $\%$ & $\%$ & $\%$ & $\%$ \\
\hline Saudi Arabia & 2.2 & 1.2 & 2.1 & -0.8 & 2.6 \\
UAE & 2.3 & 4.1 & 1.6 & 2.0 & 3.5 \\
Kuwait & 2.9 & 3.3 & 3.2 & 2.2 & 0.8 \\
\hline
\end{tabular}

Source: The World Bank*, MOF of Saudi Arabia, UAE, and Kuwait**

Table 4 showed the budget balancing strategies that GCC countries adopted during and after the oil crisis of 2014. Distinctions in using budget balancing tools are clear among the three countries, which contributed to their variation in budget outcomes during and after the crisis. In particular, countries that implemented revenue-increasing policies were more likely to successfully close the gap in the budget. For example, Saudi Arabia and UAE introduced the VAT in January 2018. According to reports from Saudi Ministry of Finance, the new taxes introduced in 2018 had generated annual revenue of more than 26.6 billion dollars (Saudi Ministry of Finance, 2019). Also, the UAE was able to receive 6.7 billion dollars in revenues (UAE Ministry of Finance, 2019). On the other hand, Kuwait did not introduce VAT to date (Kuwait Ministry of Finance, 2019).

Table 4. Various Budget Balancing Strategies Adopted by Countries

\begin{tabular}{|c|c|c|c|c|c|c|c|c|c|c|c|c|c|c|c|c|c|c|}
\hline Type & & VAT & & & $\begin{array}{l}\text { ees } \\
\text { xes }\end{array}$ & & & ubs & & & get & & & $\begin{array}{l}\text { vere } \\
\text { lth F }\end{array}$ & & & $\begin{array}{l}\text { plo } \\
\text { efit }\end{array}$ & \\
\hline Year & 约 & 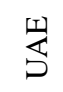 & 3 & $\underset{\sim}{\mathbb{S}}$ & 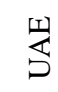 & 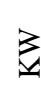 & 洗 & 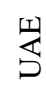 & 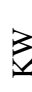 & $\underset{\sim}{\mathbb{2}}$ & 峁 & 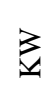 & $\underset{\sim}{\mathbb{Z}}$ & 岕 & 3 & 约 & 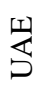 & 3 \\
\hline 2014 & & & & & & & & $X$ & & & & & & & & & & \\
\hline 2015 & & & & & & & & $X$ & & $X$ & X & X & $X$ & $X$ & X & & & \\
\hline 2016 & & & & $X$ & $X$ & & & $X$ & & $X$ & & $X$ & $X$ & $X$ & $X$ & $X$ & & \\
\hline 2017 & & & & $X$ & $X$ & & $X$ & $X$ & & & & $X$ & $X$ & & & & & \\
\hline 2018 & $X$ & $\mathrm{X}$ & & $X$ & $X$ & $X$ & $X$ & $\mathrm{X}$ & & & & & $X$ & & & & & \\
\hline
\end{tabular}

\section{Discussions}

This study was designed to compare the budget-balancing strategies that three GCC countries had utilized during and after the oil crisis of 2014. Using comparative analysis enabled the study to examine the policies implemented by each country and assess the impact on the economy. In this section, a discussion of each country's budget-balancing strategies and the policies implemented are provided.

Among these three countries, UAE was more successful than Saudi Arabia and Kuwait in closing the gap in the budget. The review of UAE's budget-balancing strategies during and after the economic recession of 2014 
suggests that the country applied a balanced-approach that placed equal importance into revenue-increasing measures and expenditure cutting strategies in order to cope with the most severe budget shortfalls in FY 2015 and FY 2016. In the following fiscal years, UAE focused more on revenue generating policies to improve revenue collections and cover budget deficits. Using such strategies, the UAE was able to keep its revenue growth stable over time and significantly increase its budget in FY 2018 (Fouejieu, Rodriguez, \& Shahid, 2018; Garcia \& Hénin, 1999; UAE Ministry of Finance, 2019).

Saudi Arabia reduced most of its budget shortfalls that it encountered in 2014. An examination of Saudi Arabia budget-balancing strategies indicates that withdrawing from sovereign wealth funds or introducing expenditure-reducing policies, such as employee benefits cuts were most frequently adopted as the oil crisis lingered (Sultan \& Haque, 2018). However, these strategies did not improve the economy. In fact, they might have contributed to the deflation that the Saudi Arabian economy experienced in FY 2017. Nevertheless, Saudi Arabia's utilization of revenue-increasing policies such as the introduction of VAT was one of the most successful budget-balancing tools that was implemented (Garcia \& Hénin, 1999; Saudi Ministry of Finance, 2019). The country's economy had generated double the projected revenues for the FY 2018.

Kuwait mostly applied cuts across the budget to reduce public spending, and relied heavily on oil revenues cover budget shortfalls. Kuwait implemented few strategies that are related to revenue enhancement. Unlike UAE and Saudi Arabia, Kuwait did not introduce VAT nor decrease subsidies for gas and oil. Kuwait would continue to face the most fiscal problems in balancing revenues with expenditures once oil prices drops. Also, unlike UAE and Saudi Arabia, Kuwait is 12\% short of their 2014 budget revenue (Alkhateeb et al., 2017; El-Katiri, 2016; Fattouh et al., 2015; Kuwait Ministry of Finance, 2019).

\section{Conclusion}

In this study, an investigation was conducted to assess the impact of budget shortfalls in three GCC countries with a specific focus on their economic tools selections of budget-balancing strategies in response to the oil crisis in 2014. Based on previous literature and study of the three countries, this paper categorized budget balancing strategies into several types utilizing secondary data from MoFs and IMF reports (Belmont, 2016; IMF, 2017). For example, the mere existence of sovereign wealth fund did not guarantee the avoidance of hardship during severe budget shortfall (Garcia \& Hénin, 1999; Maghyereh, Awartani, \& Tziogkidis, 2017). In fact, all three countries had to consider other strategies to cope with the oil crisis of 2014. However, the implementation of revenue-increasing and expenditure-reducing policies varies across countries.

This study underpinned the fact that policies implemented by governments have a huge impact on the economy (Alkhateeb, Sultan, Mahmood, 2017). Selecting the right budget-balancing strategy can help the country close the gap in the budget and promote economic growth (Shi, 2016; Garcia \& Hénin, 1999). Relying heavily on oil production for revenue is not sustainable. GCC countries ought to continue assessing the impact of each policy implemented as social, economic, and political conditions might shift (Maghyereh, Awartani, \& Sweidan, 2017).

The evaluation of budget-balancing strategies for these countries showed that there were distinct patterns in use of strategies. Findings of this study indicated that countries which implemented strategies with different focuses such as either revenue increasing or expenditure reducing would produce different outcomes and economic growth (Sultan \& Haque, 2018). This conclusion is consistent with previous literature regarding budget-balancing strategies (Shi, 2016; Belmont, 2016; Sultan \& Haque, 2018). Future research could broaden the investigation scope to include other GCC countries and utilize different social and economic growth indicators to assess the impact of policy on budget.

\section{Limitations}

This study is limited to three GCC countries (Saudi Arabia, UAE, and Kuwait) because data was only accessible in these countries during the time the investigation. Also, the analysis is constrained by the timeframe and data resource available from 2014 to 2018 .

\section{Acknowledgement}

The author wish to acknowledge the support of King Saud University, which funded this study via grants.

\section{References}

Alkhateeb, T. T. Y., Sultan, Z. A., \& Mahmood, H. (2017). Oil revenue, public spending, gross domestic product and employment in Saudi Arabia. International Journal of Energy Economics and Policy, 7(6), 27-31.

Altman, R. C., \& Haass, R. N. (2010). American profligacy and American power: the consequences of fiscal irresponsibility. Foreign Affairs, 25-34. 
Belmont, C. J. (2016). A Critical Examination of Oil Wealth Management Strategies and Their Effects on Economic Growth in the Gulf Cooperation Council Countries.

Bouri, E. (2015). Oil volatility shocks and the stock markets of oil-importing MENA economies: A tale from the financial crisis. Energy Economics, 51, 590-598. https://doi.org/10.1016/j.eneco.2015.09.002

El-Katiri, L. (2016). Vulnerability, Resilience, and Reform: The GCC and the Oil Price Crisis 2014-2016. El-Katiri, Laura, New York: Columbia University Center on Global Energy Policy.

Fattouh, B., Poudineh, R., \& Sen, A. (2015). The dynamics of the revenue maximisation-market share trade-off: Saudi Arabia's oil policy in the 2014-2015 price fall. https://doi.org/10.26889/9781784670412

Fouejieu, M. A., Rodriguez, S., \& Shahid, M. S. (2018). Fiscal Adjustment in the Gulf Countries: Less Costly than Previously Thought: International Monetary Fund. https://doi.org/10.5089/9781484361573.001

Garcia, S., \& Hénin, P. Y. (1999). Balancing budget through tax increases or expenditure cuts: is it neutral? Economic Modelling, 16(4), 591-612. https://doi.org/10.1016/S0264-9993(99)00016-4

Haque, M. I., \& Khan, M. R. (2019). Role of Oil Production and Government Expenditure in Improving Human Development Index: Evidence from Saudi Arabia. International Journal of Energy Economics and Policy, 9(2), 251-256.

IMF. (2017). How Can Growth-Friendlier Expenditure-Based Fiscal Adjustment be Achieved in the GCC? Retrieved from https://www.imf.org/en/Publications/Policy-Papers/Issues/2017/12/14/pp121417gcc-expenditure-based-fisc al-adjustement

IMF. (2018). How Should GCC Countries Diversify Their Economies And Promote Inclusive Growth? Retrieved from

https://www.imf.org/en/News/Articles/2018/12/07/NA120918-how-should-gcc-countries-diversify-their-ec onomies-and-promote-inclusive-growth

IMF. (2019). World Economic and Financial Surveys: World Economic Outlook Database Retrieved from https://www.imf.org/external/pubs/ft/weo/2019/01/weodata/index.aspx

Ivanova, O., Romanova, T., Kostoglodova, E., \& Romanov, D. (2017). Strategic Directions of the Country's Ensuring Financial Security. European Research Studies, 20(3B), 461.

Kuwait Ministry of Finance (2019) Kuwait Public Budget: Financial Reports Retrieved from http://www.mof.gov.kw/FinancialData/EconomicTeamArchiveReport.aspx

Maghyereh, A. I., Awartani, B., \& Sweidan, O. D. (2017). Oil price uncertainty and real output growth: new evidence from selected oil-importing countries in the Middle East. Empirical Economics, 1-21. https://doi.org/10.1007/s00181-017-1402-7

Maghyereh, A. I., Awartani, B., \& Tziogkidis, P. (2017). Volatility spillovers and cross-hedging between gold, oil and equities: Evidence from the Gulf Cooperation Council countries. Energy Economics, 68, 440-453. https://doi.org/10.1016/j.eneco.2017.10.025

Ndjokou, M. M. (2013). Fiscal policy and growth: an empirical evaluation in CFA franc zone. International Business Research, 6(7), 131. https://doi.org/10.5539/ibr.v6n7p131

Presley, J. R., \& Westaway, T. (2017). A guide to the Saudi Arabian economy: Springer.

Raudla, R., Douglas, J. W., Savi, R., \& Randma-Liiv, T. (2017). Fiscal crisis and expenditure cuts: The influence of public management practices on cutback strategies in Europe. The American Review of Public Administration, 47(3), 376-394. https://doi.org/10.1177/0275074016661029

Ragin, C. (1987): The Comparative Method: Moving beyond Qualitative and Quantitative Strategies. Berkeley: University of California Press.

Saudi Arabia Ministry of Finance (2019) Saudi Arabian Budget Reports Retrieved from https://www.mof.gov.sa/en/financialreport/Pages/default.aspx

Shi, Y. (2016). State budget shortfalls and budget balancing strategies during and after the great recession of 2008. Journal of Public Budgeting, Accounting \& Financial Management, 28(1), 26-47. https://doi.org/10.1108/JPBAFM-28-01-2016-B003

Sultan, Z. A., \& Haque, M. I. (2018). Oil exports and economic growth: An empirical evidence from Saudi Arabia. International Journal of Energy Economics and Policy, 8(5), 281-287. 
Truman, E. M. (2009). A blueprint for sovereign wealth fund best practices. Revue d'economie Financiere, 9(1), 429-451. https://doi.org/10.3406/ecofi.2009.5526

United Arab Emirates Ministry of Finance (2019) MoF Budget Archive: A Collection of the UAE's Financial Records Retrieved from https://www.mof.gov.ae/en/resourcesAndBudget/fedralBudget/Pages/budgetArchive.aspx

World Bank. (2019). WorldBank Microdata Data Catalog: Saudi Arabia Retrieved from https://data.worldbank.org/country/saudi-arabia

World Bank. (2019). WorldBank Microdata Data Catalog: United Arab Emirates Retrieved from https://data.worldbank.org/country/united-arab-emirates?view=chart

World Bank. (2019). WorldBank Microdata Data Catalog: Kuwait Retrieved from https://data.worldbank.org/country/kuwait

\section{Copyrights}

Copyright for this article is retained by the author(s), with first publication rights granted to the journal.

This is an open-access article distributed under the terms and conditions of the Creative Commons Attribution license (http://creativecommons.org/licenses/by/4.0/). 